\title{
СРАВНИТЕЛЬНАЯ ХАРАКТЕРИСТИКА МЕХАНИЧЕСКОЙ ЖЕЛТУХИ РАЗНОГО ГЕНЕЗА
}

\section{COMPARATIVE CHARACTERISTICS OF MECHANICAL JARCUS DIFFERENT GENESIS}

\section{Shalin \\ E. Troshin \\ I. Vashurkina \\ G. Smirnova \\ V. Kozharinov \\ S. Shalina}

Summary. Jaundice is a clinical syndrome that occurs due to a violation of the metabolism of bilirubin in body fluids and tissues, characterized by icteric staining of the skin, sclera and mucous membranes. In modern surgery, this syndrome occurs in many acute and chronic diseases of both hepatobiliary and many other systems. Obstructive jaundice is of particular interest to the surgeon. However, diagnostics based only on external clinical signs hides various causes of occurrence. Obstructive jaundice of a tumor and non-tumor nature presents not only difficulties in differential diagnosis, but also in the choice of tactics of conservative and surgical treatment.

Keywords: obstructive jaundice, gallbladder, surgery, tumor, calculi.
Шалин Владислав Витальевич

ФГБОУ ВО «Национальный исследовательский Мордовский государственный университет им. Н.П. Огарева» vladshalin190@gmail.com

трошин Евгений Михайлович

ФГБОУ ВО «Национальный исследовательский Мордовский государственный университет им. Н.П. Огарева» jeka.troshin@mail.ru

Вашуркина Ирина Михайловна

К.м.н, доцент, ФГБОУ ВО «Национальный Исследовательский Мордовский государственный университет им. Н.П. Огарева» impolyakova@ya.ru

Смирнова Галина Васильевна

К.м.н., дочент, ФГБОУ ВО «Национальный исследовательский Мордовский государственный университет им. Н.П. Огарева» galina.cmirnova-g@yandex.ru

Кожаринов Владислав Святославович Врач травматолог-ортопед, Пензенская областная клиническая больница им. Н.Н. Бурденко

Шалина Светлана Владимировна

Врач-ревматолог, Пензенская областная клиническая больница им. Н.Н. Бурденко

Аннотация. Желтуха — клинический синдром, возникающий из-за нарушения обмена билирубина в жидкостях и тканях организма, характеризующийся желтушным окрашиванием кожных покровов, склер и слизистых оболочек. В современной хирургии данный синдром встречается при множестве острых и хронических заболеваний как гепатобилиарной, так и многих других систем. Отдельный интерес для врача-хирурга представляет механическая желтуха. Однако диагностика только по внешним клиническим признакам скрывает в себе различные причины возникновения. Механическая желтуха опухолевой и неопухолевой природы представляет собой не только сложности в дифференциальной диагностике, но и в выборе тактики консервативного и оперативного лечений.

Ключевые слова: механическая желтуха, желчный пузырь, хирургия, опухоль, конкременты. 


\section{К^ассификашия}

$\mathbf{M}$ еханическая желтуха развивается и прогрессирует в связи с нарушением оттока желчи на различных уровнях желчевыводящих путей. В современной классификации причин данного синдрома выделяют: пороки развития (атрезия, гипоплазия), доброкачественные заболевания (желчекаменная болезнь, стриктуры и стенозы желчных протоков), воспалительные процессы (холециститы, холангиты, панкреатиты, папиллиты), злокачественные новообразования (рак гепатобилиарной и панкератодуоденальной систем), паразитарные и бактериальные заболевания (эхинококкоз, абсцесс)[1].

\section{Патогенез}

Возникновению механической желтухи способствуют многие патофизиологические изменения, включающие в себя недоедание, острую почечную недостаточность и инфекции, которые могут быть смертельными.

Анатомо-физиологические взаимосвязи печени, желчного пузыря и внепеченочных желчевыводящих путей приводят к их совместному поражению при хронических формах механической желтухи. Возникновению данной патологии способствуют недоедание, острая почечная недостаточность и инфекции, которые могут быть смертельными. Морфофункциональные особенности нарушения обменных процессов в печени, наличие сопутствующих факторов значительно усугубляют течение заболевания, что повышает риск возникновения осложнений и смертельных исходов во время проведения операций.[2]

Гипертензия во внутрипеченочных желчных ходах приводит к их разрыву и гепатоциты пропитываются желчью. Желчное пропитывание приводит к некрозу клеток печени, снижается потребление кислорода и нарушаются процессы окислительного фосфорилирования. Желчная гипертензия также вызывает расширение просвета и утолщение стенок протоков. Резкое изменение соотношения просвет/толщина стенки, некроз гепатоцитов, холангит приводят к застою желчи и возникновению более тяжелых воспалительных реакций.[3]

Холестаз, возникающий в результате механической обструкции, быстро приводит к холестатической интоксикации, холангитов, печеночно-клеточной недостаточности, что выражается в прогрессировании нарушений детоксикационной и синтетической функций печени.[4]

Нарастание печеночно-клеточной недостаточности, длительный механический спазм являются одной из наиболее частых причин летального исхода. Это связано с тяжелыми морфофункциональными, гемодинамическими и гомореологическими нарушениями.[5]

Длительное течение желчной гипертензии оказывает прогрессирующее деструкционно-некротическое действие на гепатоциты. Это ведет к нарушению структуры и свойств клеточных мембран в результате изменения количественного и качественного состава мембранных липидов, холестерина, желчных кислот, мембраносвязынных ферментов и белков-траспортеров.[6]

у больных с механической желтухой печеночный кровоток уменьшается более чем наполовину. Снижение кровотока печени напрямую зависит от длительности блокады желчных путей. Низкий кровоток приводит к гипоксии, в результате которой усиливаются явления гликолиза, уменьшаются запасы гликогена в печени и дегенерация фосфолипидов клеточных мембран и впоследствии приводит к гибели гепатоцитов. Данное состояние губительно влияет даже на интактную печень. Ишемия ткани печени приобретает токсическую активность в результате центролобулярно расположенных гепатоцитов, которые находятся в зоне с низким уровнем снабжения кислородом. Возникающая печеночная недостаточность расценивается как срыв компенсаторных возможностей печени и развитие метаболического ацидоза.[7]

В условиях механической обструкции происходит изменение архитектоники паренхимы печени, соединительнотканного компонента, эпителиальных и мышечных элементов, нервно-сосудистого аппарата и системы протоков. Это проявляется фиброзированием желчного пузыря, гипертрофией мышечной оболочки кровеносных сосудов, их дилатация, в особенности венозной и лимфатических систем. При обтурации общего желчного протока изменения более выраженные, чем при медленно нарастающей обтурации.[8]

Морфологические изменения печени приводят к функциональным нарушениям физиологически взаимосвязанных систем организма, в результате действия продуктов аутолиза, так и при нарушении желчепродуцирующей, так и детоксикационной функций. Патофизиологически значимое влияние на состояние всех органов и систем оказывает гепатогенная интоксикация. Основными клинически значимыми симптомами являются синдромы желтух, холестаза, цитолитическипй, мезенхимально-воспалительный, портальной гипертензии, гепаторенальный, геморрагический. В результате нарушения функции детоксикации, деструкции и некроза клеток печени в кровеносной системе накапливаются различные биохимические вещества 
(аммиак, билирубин, свободные жирные кислоты, полиамины, производные индола и фенола, мочевина и креатинин). Накапливающиеся метаболиты при печеной недостаточности дают вторичный гепатотропныый эффект: они поражаются окислительную систему печени, что выражается в гепатоцеребральной недостаточности.[9]

Нередко у пациентов с механической желтухой наблюдаются тромбогеморрагичесие осложнения. Основная роль в их развитии принадлежит следующим системам - свертывающей, фибринолитической, калликреин-кининовой. Нарушения микрореологии, коагуляции, микротромбоэмболий, повышение проницаемости капилляров лежит в основе нарушения кровообращения жизненной важных органов, что выражается в виде печеночно-почечного синдрома. [10]

Характерные для механической желтухи гемодинамические нарушения включают брадикардию, обусловленную рефлексом, возникающим при механическом растяжении желчных протоков, повышение сердечного выброса, сосудистой проницаемости и вазодилатацию. Снижение артериального давления связано с действием желчных кислот на рецепторы и центр вагуса, на узел Киса-Флака и кровеносные сосуды. Перечисленные факторы требуют большого количества жидкости и большого ударного объема сердца, чтобы поддержать артериальное давление и диурез.[11]

Длительное нарушение проходимости желчных путей может стать причиной мальабсорбции жиров и стеатореи. В связи с нарушением энтерогепатического кровообращения жирорастворимые витамины перестают всасываться. Дефицит таких витаминов как A, D, Е и К приводят к ночной слепоте, рахиту, нарушению нервно-мышечной проводимости и нарушению свертываемости крови соответственно. [12]

\section{Бактериальная флора}

Наличие или попадание патогенных и условно-патогенных микроорганизмов, их персистенция и выделение продуктов жизнедеятельности может стать причиной возникновения инфекционных процессов, что также приведет к возникновению механической желтухи и даже будет осложнять её течение. В условиях нормальной физиологии, сфинктер Одди представляет собой естественный защитный барьер для проникновения бактерий из двенадцатиперстной кишки ретроградно. В свою очередь, сфинктер Люткенса препятствует проникновению бактерий в желчный пузырь, но не препятствует возникновению холангитов. Также имеет место быть гематогенное или лимфогенное через печеночную артерию, портальную вену или через печеночные лимфатические узлы. Оперативные вмешательства, такие как эндоскопическая ретроградная папиллосфинктеротомия, холангиоэнтеростомия, установка стентов в желчные пути могут привести к системной воспалительной реакции и увеличивают риск возникновения сепсиса в результате бактериемии и токсинемии. [13]

Микроорганизмы, культивируемые из желчи больных с холецистохолангитом в основном включают: грамотрицательные - Escherichia coli, виды Klebsiella, Proteus, Pseudomonas; грамположительные Streptococcus и Enterobacter. Поэтому при лечении механической желтухи, сопровождаемой бактериемией, применяют антибиотики или антибактериальный препараты, в спектр которых входят высеянные микроорганизмы. [14]

\section{КАИника}

Клиническая симптоматика складывается из жалоб пациента, данных внешнего осмотра и данных лабораторно-инструментальных методов исследования.

Характерными симптомами механической желтухи являются: боль, изменения цвета кожных покровов и склер, кожный зуд, снижение массы тела и аппетита, лихорадка.

Боль - наиболее частый спутник механической желтухи. Причинами возникновения могут быть инвазии или компрессии опухолью нервных стволов; обструкция желчными камнями желчного или вирсунгова протока, симптомами раздражения брюшины в результате обострения панкреатита.

При опухоли головки поджелудочной железы боль локализуется в правой подреберной или надчревной области; при поражении тела и хвоста болевые ощущения находятся в левом подреберье или эпигастрии, но может и проявляться болями в правом подреберье. Для диффузного поражения характерна боль в верхних отделах живота. Часть пациентов описывают боль в одном месте, другие описывают иррадиацию в позвоночник, межлопаточную области или под правую лопатку. При компрессии вирсунгова протока больной описывает приступообразную опоясывающую боль.[15]

Болевые ощущения чаще всего возникают в позднее время суток, при положении лежа на спине, после погрешности в диете. При раке тела поджелудочной железы боль становится нестерпимой, особенно при прорастании или компрессии солнечного сплетения. В связи с этим больные принимают вынужденное положение, так называемую позу «крючка».[16] 
Симптом желтух - клинически важный симптом, проявляющийся пожелтением мочи, видимых слизистых оболочек, склер. Это связано с накоплением билирубина в клетках кожи и слизистой в результате его повышенного содержания в крови. Пациент жалуется на изменение цвета кожи и ярко выраженный кожный зуд в результате раздражения желчными кислотами чувствительных нервных окончаний. [17]

Холестаз - носит характер нарушения и полного прекращения поступления компонентов желчи, застоем в протоке и возможным пропитыванием в кровь. Проявляется повышением в крови количества биохимических маркеров холестаза, синдромами холемии и ахолии. Биохимические маркеры - прямой билирубин, холестерин, липопротеины, фосфолипиды, холаты. Также отмечается повышение уровня экскреторных ферментов: ЩФ(щелочная фосфатаза), ГГТП(гамма-глутамил-транспептидаза), ЛАП(лейцин-амино-пептидаза), 5-нуклеотидаза. [18]

Холемия формируется из-за попадания желчных кислот в кровеносную систему. Характеризуется брадикардией, тенденцией к гипотонии в результате действия на блуждающий нерв, синусовый узел сердца и кровеносные сосуды. Токсикогенное действие желчных кислот на центральную нервную систему проявляется астено-вегетативным синдромом: раздражительность, депрессии, нарушения сна, головная боль, снижение работоспособности. Моча характеризуется снижением поверхностного натяжения, вспениванию и изменению цвета - моча цвета «пива». Наличие большого количества кислот в крови вызывает гемолиз эритроцитов возникает гемолитическая желтуха, что еще больше ухудшает клиническую симптоматику. [19]

Ахолия возникает в результате отсутствия поступления желчи в просвет кишечника. При этом наблюдается расстройства пищеварения. Благодаря отсутствию желчи не активируется липаза, поэтому жиры не эмульгируются, жирорастворимые комплексы не образуются. В результате большая часть жиров не переваривается и выходит с калом - стеаторея. Нарушение переваривания белков носит название креаторея. Помимо всего прочего нарушается всасывание жирорастворимых витаминов, что приводит к возникновению других заболеваний, связанных с авитаминозами. Снижается моторика кишечника, перистальтические волны становятся меньше, возникают запоры. Но запоры могут чередоваться с поносами в результате активации процессов гниения и брожения. Кал обесцвечен из-за отсутствия стеркобилина. [20]

Снижение общей массы тела также является одним из опорно-диагностических критериев при постановке диагноза. Она обусловлена интоксикацией за счет прогрессирующей опухоли и нарушением пищеварения в кишечнике из-за закупорки желчно-панкреатических протоков. Данное клиническое проявление нередко возникает первым, что позволяет заподозрить проблемы в гепатобилиарной системе. [21]

Потеря массы тела является одним из наиболее важных симптомов. Она обусловлена интоксикацией за счет развивающейся опухоли и нарушением кишечного пищеварения в результате закупорки желчных и панкреатических протоков. Похудание наблюдается у большинства больных, иногда бывает первым симптомом заболевания, предшествуя появлению боли и желтухи. [21]

\section{Особенности течения}

Пороки развития - характерно для детского возраста, желтушность с рождения, при отсутствии хирургического лечения могут умереть от билиарного цирроза печени

Желчекаменная болезнь - в анамнезе калькулезный холецистит, холецистохолангит, приступы желчной колики. В дожелтушный период - боли в правом подреберье с иррадиацией различной локализации, диспептические расстройства, моча цвета «пива», ахоличный кал, кожный зуд. Часто бывают рецидивы. На УзИ - биларная гипертензия, конкременты желчного пузыря и протоков. ЭРХПГ - наличие конкрементов в холедохе или устье большого дуоденального сосочка. [22]

Инфекционно-воспалительные заболевания острое начало в результате нарушения диеты, сильнейшие боли в правой подреберной или эпигастральной областях, типична иррадиация в позвоночник и под правую лопатку. Клинические и лабораторно-инструментальные признаки заболевания. При паразитарных кистах преджелтушный период длительный в результате роста кисты. Боль тупая, ноющая, усиливающаяся при наклонах туловища. [23]

Опухолевые поражения - медленно прогрессирующее нарастание безболевой желтухи, манифестация интенсивным кожным зудом, раковая интоксикация, пальпируется увеличенный в размерах безболезненный желчный пузырь, хронические боли в верхних отделах живота. На инструментальных метода обследования опухоли поджелудочной железы. При раке Фатерова сосочка - желудочно-кишечное кровотечение. [24]

Послеоперационные стриктуры - в анамнезе операция на панкреатобилиарной зоне. Инструментальные признаки стриктуры на УЗИ и ЭРХПГ. 
Другие причины - при обильном приеме красящего вещества, например каротин или акрихин. Также следует помнить о функциональных гипербилирубинемиях, развивающихся благодаря врожденным энзимопатиям и нарушению обмена билирубина. Наиболее часто встречающимися.

\section{^ечение}

Выбирая метод лечения, стоит отметить, что консервативное лечение неэффективно, т.к. этиологический фактор механической желтухи состоит в обструкции желчевыводящих путей. Поэтому оперативное лечение будет наиболее эффективно, независимо от причины возникновения.

Bсе методы оперативного лечения механической желтухи можно условно подразделить на травматические, малоинвазивные и паллиативные.

К травматическим можно отнести открытую холецистэктомию от шейки и от дна, открытая литоэкстракция, удаление опухоли с наложением билио-билиарных анастомозов.

Для доступа к желчным органам используют либо косые разрезы вдоль правой реберной дуги (Кохера, Курвуазье), либо угловые (Федорова, Рио-Бранко). Данные доступы являются довольно травматичными, т.к. при послойно рассечении повреждаются прямые мышцы живота. Нарушение их целостности приводит возникновению посттравматического слабого места передней брюшной стенки с формирование вентральной грыжи. При визуализации места операционного приема дальнейший ход операции зависит от причины возникновения желтухи. Это холецистэктомия от шейки или от дна, литоэкстрация с наложением швов в поперечном направлении, билиобилиарный анастомоз с использованием микрососудистых техник. [25]

Малоинвазивные техники набирают все большую популярность благодаря их атравматичности и хорошему косметическому эффекту. После наложения карбоксиперитонеума в параумбиликальную область устанавливают троакар и вводят лапороскоп. Под видео контролем вводят остальные троакары: субксифоидальная область, правое подреберье по срединно-ключичной линии, правое подреберье по передней подмышечной линии. Дальнейшая техника как при обычной холецистэктомия: выделение всех структур, клипирование, удаление пузыря и перитонизация ложа. Отличие SILS-порта и трансвагинального способа только в выборе точки доступа, виде и количества инструментов. [26]

Эндоскопическая ретроградная панкреатохолангиография с эндоскопической папиллосфинктеротомией является наиболее оптимальным методом лечения при рубцовых стриктурах фатерова сосочка, околососковом расположении желчных камней и функциональном спазме мышц сосочка. На конце эндоскоп имеется металлическая проволока, которая методом электрокоагуляции рассекает большой дуоденальный сосочек на нужную ширину. [27]

\section{Зак^ючение}

Механическая желтуха - это серьезнейшая патология, которая требует незамедлительного устранения причины обструкции. Практически во всех случаях показано оперативное лечение. Тактика должна определяться видом заболевания, состоянием пациента и наличием соответствующего оборудования.

\section{ЛИТЕРАТУРА}

1. Стяжкина С.Н., Гадельшина А.А., Ворончихина Е.М. Аспекты динамики и лечения механической желтухи // Наука и образование сегодня. № 3 (14), 2017. С. 46.

2. Хаданов А.А., Привалов Ю.А., Неустроев В.Г., Журавлев С.В., Гумеров Р.Р., Егоров И.А. Механическая желтуха как мультидисциплинарная проблема. Клинический случай. Сибирское медицинское обозрение. 2020;(1):89-95.

3. Аксель Е.М. Статистика злокачественных новообразований желудочно-кишечного тракта. Сибирский онкологический журнал. 2017;16(3):5-11.

4. Патютко Ю.И., Котельников А.Г., Мороз Е.А., Кудашкин Н.Е., Ястребова Е.В. Лечение больных раком большого дуоденального сосочка. Анналы хирургии. 2016;(1-2): 74-81.

5. Хоронько Ю.В. Синдром «быстрого» билиарной декомпрессии при лечении механической желтухи / Ю.В. Хоронько, В.Л. Коробка, В.С. Грушилин и др. // Анналы хирургической гепатологии.-2019-Том $24-$ № $4-$ С. 24-29.

6. Карпов 0.Э., Ветшев П.С., Бруслик С.В., Маады А.С., Левчук А.Л., Свиридова Т.И. Сочетанное применение миниинвазивных технологий в лечении механической желтухи. Анналы хирургической гепатологии. 2019;24(2):100-104.

7. Котовский А.Е. Ретроградное эндопротезирование желчных протоков при доброкачественных заболевания органов гепатопанкреатодуоденальной зоны / А.Е. Котовский, К.Г. Глебов, Т.Г. Дюжева и др. // Анналы хирургической гепатологии.-2019. — Том 24. — № 1 — C. 61-70.

8. Pavlidis E.T. Pathophysiological consequences of obstructive jaundice and perioperative management / E.T. Pavlidis, T.E. Pavlidis // Hepatobiliary Pancreat. Dis. Int.—2018.—vol.—17.— № 1-pp.17-21. 
9. Федоров В.Э., Захарова Н.Б., Логвина 0.А., Масляков В.В. Оценка степени тяжести больного при остром холецистите и механической желтухе в свете национальных клинических рекомендаций (обзор литературы). Экспериментальная и клиническая гастроэнтерология. 2019;(3):97-104.

10. Пахомова Р.А., Кочетова Л.В. Клинические проявления механической желтухи и печеночной недостаточности в зависимости от степени тяжести механической желтухи доброкачественного генеза. Современные проблемы науки и образования. Электронный научный журнал. 2017;(6).

11. Каприн А.Д., Старинский В.В., Петрова Г.В. Злокачественные новообразования в России в 2017 году (заболеваемость и смертность) / М.: МНИоИ им. П.А. Герцена, филиал ФГБУ «НМИЦ радиологии» Минздрава России, 2018. -250 c.

12. Стяжкина С.Н. Механическая желтуха — основное осложнение гепатопанкреатобилиарной системы / С.Н. Стяжкина, А.А. Гадельшина, Е.М. Ворончихина // Вестник науки и образования. - 2017. - Т. 1. № 5 (29).- - С. 103-105.

13. Р.К. Бейшенбаев, С.Ш. Сапаров, Б.А. Авасов. Приоритетные направления в диагностике больных с механической желтухой различного генеза // Вестник КГМА им. И.К. Ахунбаева. — 2017. — № 2. С. 94-96

14. Шалин В.В., Маркосьян С.А., Теричев А.Е., Гечас А.А., Тетюшкин Н.С. Современные Методы Малоинвазивного Лечения Заболеваний Желчного Пузыря И Желчевыводящих Путей// Международный Журнал Прикладных И Фундаментальных Исследований № 1, 2021. С. 19-23

15. Пучков К.В., Пучков Д.К. Хирургия желчнокаменной болезни: лапароскопия, минилапароскопия, единый порт, трансанальный доступ, симультанные операции. М.: ИД «МЕДПРАКТИКА-М», 2017, 312 C.

16. Базина К.А., Колосунин И.А., Кузнецова В.А., Шалин В.В., Паркин П.Н. Патогенез Механической Желтухи Обзор Литературы// Colloquium-journal № 10 (62), 2020. С. $40-47$

17. Строкова Т.В., Багаева М.Э., Матинян ИЛ. Дефицит лизо-сомальной кислой липазы // РМЖ. Педиатрия. — 2017, № 19.— С. $1346-1351$.

18. Шабунин А.В. Тавобилов М.М. Выбор способа декомпрессии желчных протоков в лечении больных механической желтухой опухолевого генеза. Российский медико-биологический вестник им. академика И.П. Павлова. 2016. Т. 24, № 1. С. 68-74.

19. Мезенцев С.С., Кит О.И., Колесников Е.Н. и др. Миниинвазивные операции желчеотведения при механической желтухе опухолевого генеза. Современные проблемы науки и образования. 2017. № 3.1

20. Вахрушев Я.В. От симптома к диагнозу: Учебное пособие / Ижевск: Издательство «Шелест», 2016. 197 с.

21. Мохова 0.Г., Канкасова М.Н., Поздеева 0.С. Синдром желтухи в практике педиатра. Практическая медицина. 2018 Том 16, № 8, С. 43-49

22. Naureen Memon, Barry Weinberger, Thomas Hegyi and Lauren M Aleksunes Inherited Disorders of Bilirubin Clearance // Pediatr Res. — 2016. — 79(3). — P. 378-386.

23. Jagadisan B., Srivastava A. Child with Jaundice and Pruritus: How to Evaluate?// Indian J Pediatr. — 2016. — 83(11). — P. 1311-1320.

24. Eleonora Druve Tavares Priamry sclerosing cholangitis in children and adolescents // Arq. Gastroenterol.— 2017.— Vol. 54.— № .4.

25. Володин Н.Н., Дегтярев Д.Н., Дегтярева АЗ., Нароган М.В. Желтухи новорожденных. ГэОТАР-Медиа. — 2018. — 192 с

26. Захарова И.Н., Горяйнова А.К., Холодова И.Н., Майкова И.Д., Беленович Е.3., Тамбиева Е.З., Болбикова Е.3., Меленькина А.К., Худякова А.А. Дифференциальный диагноз желтух у детей раннего возраста // Медицинский совет. Гастроэнтерология. — 2016. — № 7. — C. 56-65.

27. Раманова Д.Ю., Адылова 3.У. Малоинвазивные технологии в лечении механической желтухи. European Research. 2017. № 5(28). С. 85 -86

( ) Шалин Владислав Витальевич (vladshalin190@gmail.com ), Трошин Евгений Михайлович ( jeka.troshin@mail.ru ),

Вашуркина Ирина Михайловна ( impolyakova@ya.ru ), Смирнова Галина Васильевна ( galina.cmirnova-g@yandex.ru ),

Кожаринов Владислав Святославович, Шалина Светлана Владимировна.

Журнал «Современная наука: актуальные проблемы теории и практики» 